\title{
Erratum to: Comparison of salivary and calculated free cortisol levels during low and standard dose of ACTH stimulation tests in healthy volunteers
}

Gulsah Elbuken $^{1} \cdot$ Fatih Tanriverdi $^{1} \cdot$ Zuleyha Karaca $^{1} \cdot$ Mustafa Kula $^{1}$ • Selma Gokahmetoglu ${ }^{1} \cdot$ Kursad Unluhizarci $^{1} \cdot$ Fahrettin Kelestimur $^{1}$

Published online: 3 June 2015

(c) Springer Science+Business Media New York 2015

Erratum to: Endocrine (2015) 48:439-443

DOI 10.1007/s12020-014-0378-8

Unfortunately, the acknowledgment section was not included in the original publication. The section is published with this erratum.

Acknowledgments Grant support by Erciyes University Council of Scientific Investigations (Project code: TSU-102907).

The online version of the original article can be found under doi:10.1007/s12020-014-0378-8.

Fahrettin Kelestimur

fktimur@erciyes.edu.tr

1 Kayseri, Turkey 